\title{
Estimation of the Country Ranking Scores on the Global Innovation Index 2016 Using the Artificial Neural Network Method
}

\author{
İhsan Pençe*, Adnan Kalkan ${ }^{\dagger}$ and Melike Şişeci Çeşmeli \\ Bucak Zeliha Tolunay Applied Technology and Business School \\ Mehmet Akif Ersoy University \\ Adem Tolunay Campus, BURDUR, Bucak, Turkey \\ *ihsanpence@mehmetakif.edu.tr \\ †adnankalkan@mehmetakif.edu.tr \\ †melikesiseci@mehmetakif.edu.tr
}

Received 29 September 2017

Accepted 14 October 2018

Published 23 November 2018

\begin{abstract}
The Global Innovation Index (GII) aims to rank countries using different innovation factors. This ranking list enables countries to observe their potential status according to the rankings of other countries. The countries are classified under four groups according to the World Bank Income Group Classification on the GII list. The groups are named as; low income (LI), lowermiddle income (LM), upper-middle income (UM) and high income (HI). Also, every country has a score in this ranking list. In this study, the ranking scores of 128 countries are estimated using the artificial neural network (ANN). We chose the relevant 27 features on GII 2016 Report, as input data. The significance of this paper is that; it is the first curve fitting and estimation of the score processes on GII 2016 dataset. The low root mean square error (RMSE) value which is obtained in an experimental study shows that the fitting structure is good enough to determine the approximate score of the countries in GII list. The results also show that the selected 27 features are sufficient for obtaining the income score of the countries. Increasing the number of features would lower the RMSE value and enable better approximation in the curve fitting process. The final results can assist the countries in achieving long-term output growth and improving their innovation capabilities.
\end{abstract}

Keywords: Global innovation index; information and communication technologies; curve fitting; artificial neural network.

\section{Introduction}

The rapid change we observe in almost every field today is largely due to developments in science, technology and innovation activities as our world is shaped by new technologies. From this point of view; like the development of technology is under the influence of innovation, the beginning of a new industrial revolution is called Industrial 4.0, mentioned in this study. The importance of developments in Information and Communication Technologies (ICT) and the effects of these technologies 
on national economies are increasing in developed countries. With increasing competition in the globalizing world, enterprises are trying to acquire places in markets for themselves with technological products based on the information. This situation increases the importance of technological developments and innovation day by day.

With the contribution of innovation, the changes and the developments in ICT have contributed greatly to the economies and development of the countries and raised the living standards of societies. In today's competitive environment, the driving forces of organizations and countries are technology and innovation. The word "innovation" is derived from the Latin word "innovatus" [Kantos (2016)]. Technology loses its effectiveness and importance over time unless it is supported by innovation. In addition, the new product should be accepted in the whole society. Otherwise, it is not possible to talk about innovation because there is a difference between invention and innovation, which is due to the ability to be commercially developed [Roberts (1998)].

Innovation processes today are becoming increasingly more complex because of the numerous internal and external factors surrounding the system, which need to be simultaneously addressed. Moreover, the fact that technological developments interact directly with other elements of innovation, makes the process even more complicated. Many variables are collected and analyzed so that innovation can be evaluated globally and countries can obtain information about their positions. Global Innovation Index (GII) is published by Cornell University, INSEAD, a business school, and the World Intellectual Property Organization annually. Cornell University is ranking countries using many different variables in different qualities such as the GII published annually by INSEAD and WIPO. GII aims to capture the multi-dimensional facets of innovation and provide the tools that can assist in tailoring policies to promote long-term output growth, improved productivity, and job growth. The GII helps to create an environment in which innovation factors are continually evaluated [Wunsch-Vincent et al. (2015)]. Variables used in GII data are constantly being updated and developments especially in the field of technology, which are thought to be influential on the results, are added as new variables. GII has considered the conceptual and practical challenges related to data quality and methodological choices by grouping countrylevel data across 82 indicators in the year 2016. So, there are 82 features in GII 2016 dataset.

There is a need to analyze the findings as technology develops so rapidly in the world. Artificial intelligence techniques in the field of computer science are frequently used in analyzing data and establishing various models. Artificial intelligence has various subjects such as classification, clustering, and interpolation. Interpolation or curve fitting are the processes of constructing a curve, or mathematical function that has the best fit to the original data points. Artificial Neural Network (ANN), Adaptive Neuro-Fuzzy Inference System (ANFIS) and spline curves can be used as interpolation and curve fitting techniques.

In this study, we estimated scores of the 128 countries using ANN. The curve fitting technique is used with using one output neuron in ANN design. The feedforward type neural network was preferred for fitting the data. In this study, only 27 
out of 82 features in GII 2016 dataset were selected in order to show the importance of technology and innovation in the points that determine countries' positions. So, we choose the relevant 27 features on GII 2016 Report as input data. All of the input features normalized between 0 and 1 value. Some of the selected variables are graduates in science and engineering, government's online services, online e-participation, high-tech imports and scientific and technical publications. To determine the development level of the countries and the factors affecting it is one of the most prominent issues that the countries should give importance to. Differently from other studies, it is carried out in this study that GII scores of the countries are modelled by using the ANN which is one of the artificial intelligence techniques and it is shown that it is connected to the innovation factors.

This paper is organized as follows: In Sec. 2, we discuss the theoretical framework and studies related to the GII. The research method is given in Sec. 3. In Sec. 4 the experimental studies and results are presented. Finally, we discuss the implications of our findings.

\section{Literature Review and Theoretical Framework}

When studies on innovation indicators are examined in the literature, in the field of innovation, Schumpeter [1939, 1962] stated that organizations are increasing their profits with successful innovation. Also, Schumpeter emphasized that innovation would trigger economic growth and with this Schumpeter became the first economist to associate innovation with the entrepreneur. Unlukaplan [2009], on the other hand, has carried out a study on the member countries of the European Union (EU) in order to determine the relationships between economic development, competitiveness and innovation. In his study, Unlukaplan used canonical correlation analysis for countries to conclude that there is a high correlation between economic development and innovation-competitiveness attributes.

Later, data mining methods are included in the innovation analysis and the following studies are noteworthy. Ersoz [2009], in his study, applied the Hierarchical Clustering Analysis to the innovation indicators for Turkey and a Multivariate Analysis to the innovation indicators for Europe. As a result of the analysis, Ersoz determined the cluster to which Turkey belongs. In addition, Ersoz stated that the most influential variables in innovation indicators were; the number of scientists and engineers, the number of higher education graduates, public R\&D expenditures, information and communication technology expenditures and exports of high technology products. Simsit et al. [2014] obtained five conceptual factors for GII published in 2013 by using basic component analysis in the direction of indicators determined within ICT. By using the conceptual factors and data mining techniques, 142 countries were clustered. The countries were evaluated within the framework of the 4-clustered solution obtained as a result of the clustering analysis. The findings of the research contributed to the countries in terms of evaluating their own performances, their ability to see their global position and their strategies, and gave them a new perspective. Tezcan [2015], in his study, compared EU and Turkey in terms of innovation performance by using multidimensional scaling analysis and clustering 
analysis. As a result of the analysis, it is seen that Turkey is in the same group as the countries called "Unpretentious Innovators". In the group called "Innovation Leaders"; Sweden, Finland, Denmark and Germany gathered in the same cluster and separated from other countries.

In the following years, it has been seen that studies on innovation and GII continued. Ozturk and Usakli [2013], in their study, stated that innovation should be considered in the dimension of destinations besides the business dimension. Ozturk and Usakli pointed out that the power of destination innovation depends on the power of the country's overall innovation. Baranenko et al.'s [2014] study on a concept of concluding that the level of innovation activity of an industrial enterprise directly depends on the level of its functioning and development. They emphasize external and internal environmental factors for the innovative development of the modern industrial structure. They present the modern managerial tools that are used for sustainable development of industrial enterprises in an innovative direction.

As examples of the analyses that are made on the countries or cities belonging to a specific region, the following studies can be given; Usman and Liu [2015] measure the innovation capacity and efficiency of South Asian Association for Regional Cooperation (SAARC) countries in the GII 2014. Usman and Liu suggest that the countries belong to SAARC need to strengthen the educational system for economic growth. In the study by Karadeniz et al. [2016], a total of 22 variables for Turkey were taken into account and Factor Analysis was used to calculate the statistical region units as Level-III (provinces) and 81 Statistical Region Units classification was taken into account. In the analysis of the innovation index, provinces with close innovation index values could be grouped as well as revealing the competitiveness of the provinces. As a result, developmental differences between the regions for the Level-III Regions have been revealed in Turkey. Lee et al. [2016] researched the Japanese National Systems of Innovation (NSI) through the lens of co-inventor connectivity. They compared the Japanese NSIs with their German and Danish counterparts in four representative industries. Although their study shows that Japan has produced an impressive number of patents over the past three decades, it is not well connected to other NSIs, at least through co-inventor connectivity. They show that the NSIs of other comparably advanced economies like Germany and Denmark are more connected to the global innovation systems through co-inventor connectivity.

It is also seen that other studies on innovation have been made. Hancioglu [2016] studied to determine the relationship between the variable input/output sub-index variable sets, which constitute the 2011-2015 GII of OECD countries with the help of Canonical Correlation Analysis. Crespo and Crespo [2016] apply a fuzzy-set qualitative comparative analysis to data from the GII. Crespo and Crespo [2016] examined whether innovation enablers can predict high innovation performances for two groups of countries as high-income and low-income. Sohn et al. [2016] proposed a structural equation model (SEM) based on the national innovation structure among seven factors. Using GII data from 2013, they discovered that business sophistication has the strongest direct and indirect effects on creative output, followed by infrastructure. Also, they got a new ranking using the fitted SEM. 
There are also some important works related to country risk assessment in the literature. These studies focus on the effectiveness of country risk measures and warn that the criteria may be misleading. Oetzel et al. [2001] evaluated which country risk measures can predict periods of intense instability. Their results showed that risk measures do not fully assistance in predicting and may motivate persons to ignore the true level of uncertainty they face. Bouchet et al. [2003] informed that the success of the country risk analysis is based on the underlying information. Many institutions such as central banks and rating agencies provide some information used in forecasting models. They pointed out that information like GII index has not reduced the risk of default in emerging market countries. Coccia [2007] developed a classification model of country performance and risk assessment. The proposed model uses economic and technological indicators with principal component analysis. The model can provide synthetic information about the strategic behavior of the countries in the global market.

In literature, some of the works focus on using few features and reducing variables for analyzing the country risk or developing the new measures, and some of the others focus on using all of the data that can be considered as a big data [Cruces et al. (2002); Funston and Wagner (2010)]. Funston and Wagner [2010] searched the risk management services effects for projecting standard trends. Nath [2008] shows that country risk services can failure short in terms of coverage and scope because of putting lots of all kinds of data from users. Cukier and Mayer-Schoenberger [2013] focused on big data and they suggested that using all the data not reducing the size of data features.

Vernimmen et al. [2014] inform that corporate valuation is an issue for hard forecasting of key value drivers. Also, they underline that institutional ownership affects the value of company and optimizing the value of company needs greater ownership.

Brown et al. [2015] developed a new measurement of country-level risk as a Robinson Country Risk Index. Their tool uses Governance, Economics, Operations, and Society. Kogan and Lejeune [2015] use a new method as the Logical Analysis of Data for reverse engineering and constructing the credit risk ratings. They use the multiple linear regression for measure the logical rating scores. Yang et al. [2014] focus on different measures for reducing the supply risk. They specify the external oil supply risk is an important argument of energy security and must be considered the country risk and potential oil exports capacity. Then, Liu et al. [2016] study the identification of the influence of oil price volatility on statistical properties of country risk ratings. They use the application of panel models for analyzing. Lee et al. [2017] find the relationship between oil price shocks and country risks. Rahman and Bristy [2016] try to find the level of country risk including economic, political, and financial in Bangladesh. They use International Country Risk Guide to analyze country risk. Lee and Lee [2018] study the influence of country risks on income inequality in terms of financial, political, and economic risks. They suggest that improving the country stability by searching the benefits of country risk reduction. Adem and Vuran [2018] used autoregressive distributed lag approach and error correction model for investigating the features that affect 
the account balance of Turkey. The data analysis performed for the period from September 2005 to November 2017.

Despite the fact that indexes give a false sense of security against significant risks, this study shows the importance to be given to technology in Industry 4.0.

\section{Research Method}

In this study, country ranking scores of the GII 2016 report is estimated using ANN. The curve fitting technique is used with using one output neuron in ANN design. The selected 27 features on the GII 2016 are normalized between 0 and 1 and crossvalidation technique is used for testing the GII 2016 dataset.

The GII 2016 report aims to promote global innovation as a win-win proposition and thereby is intended to facilitate improved policy making [Dutta et al. (2016)]. The GII suggested the two indices of the Innovation Efficiency Index and the GII. The GII score is the simple average of the input and output sub-indices [Sohn et al. (2016)]. Countries are ordered by a ranking score on the GII 2016 report. Country ranking scores can be seen in Table 1.

It can be seen that 128 countries are on the GII 2016 list and each country has a ranking score between 0 and 100 in Table 1 . ANN method is used for estimating these scores. It was thought that it would be possible to estimate this score with only the attributes in the field of technology and innovation, although the scores belonging to the countries are normally calculated with 82 attributes. So, technologyrelated features that have been used as ANN inputs are selected from the study of Simsit et al. [2014]. The principal component analysis, factor analysis or neuro-fuzzy classifier with linguistic hedges [Cetişli (2006)] can be used as a method for feature selection. This study focuses on innovation attributes only in Industry 4.0, so 27 of the 82 features in the GII 2016 dataset, which are specified in the Simsit et al.'s [2014] paper, have been used. Changing the number of attributes or using different attributes may change the estimated value of country scores. The 27 features used in this study and their explanations are shown in Table 2.

ANN can be used to estimate or classify problems. ANN is an artificial intelligence technique that uses interconnected nodes called neurons, inspired by biological neurons on the brain. The network is trained for finding the best weights of the connections about each neuron. ANN may use multiple layers containing multiple hidden nodes. ANN structure that has been used in this study can be seen in Fig. 1.

As seen in Fig. 1, three layers are used as input layer, hidden layer and output layer. Output layer has only one neuron that provides a curve fitting process. The feedforward type neural network preferred for fitting the data. Z1 represents country scores in Fig. 1. The Bayesian Regularization (BR) and Scaled Conjugate Gradient (SCG) algorithms are used as a learning algorithm of the ANN. While the SCG algorithm is established on the gradient descent method, BR algorithm minimizes a combination of squared errors and weights and then determines the correct combination of them.

For testing the GII 2016 dataset, 5-fold cross-validation is used. Cross-validation is a model evaluation method that can be an indication of how well the learner will 


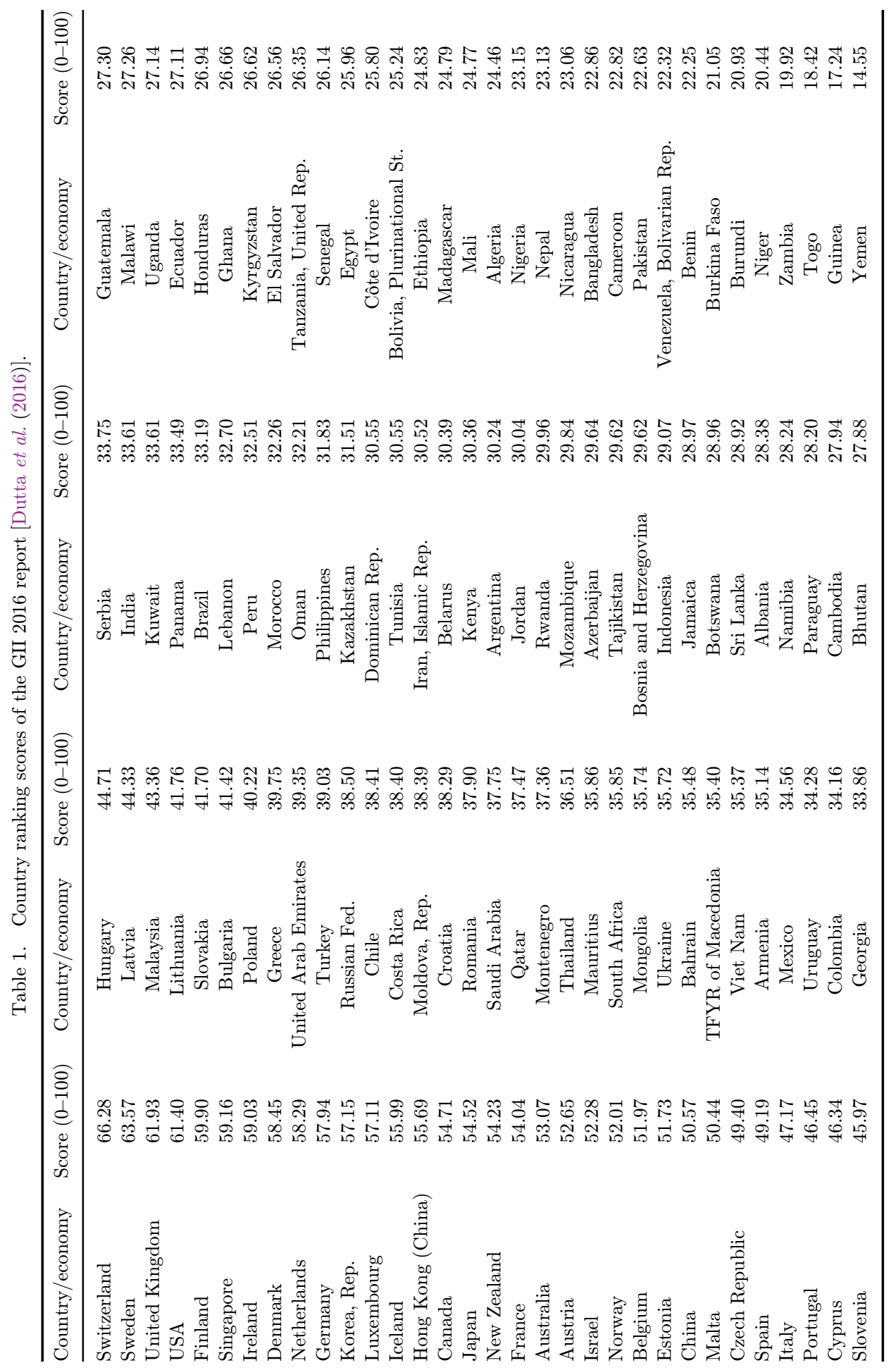




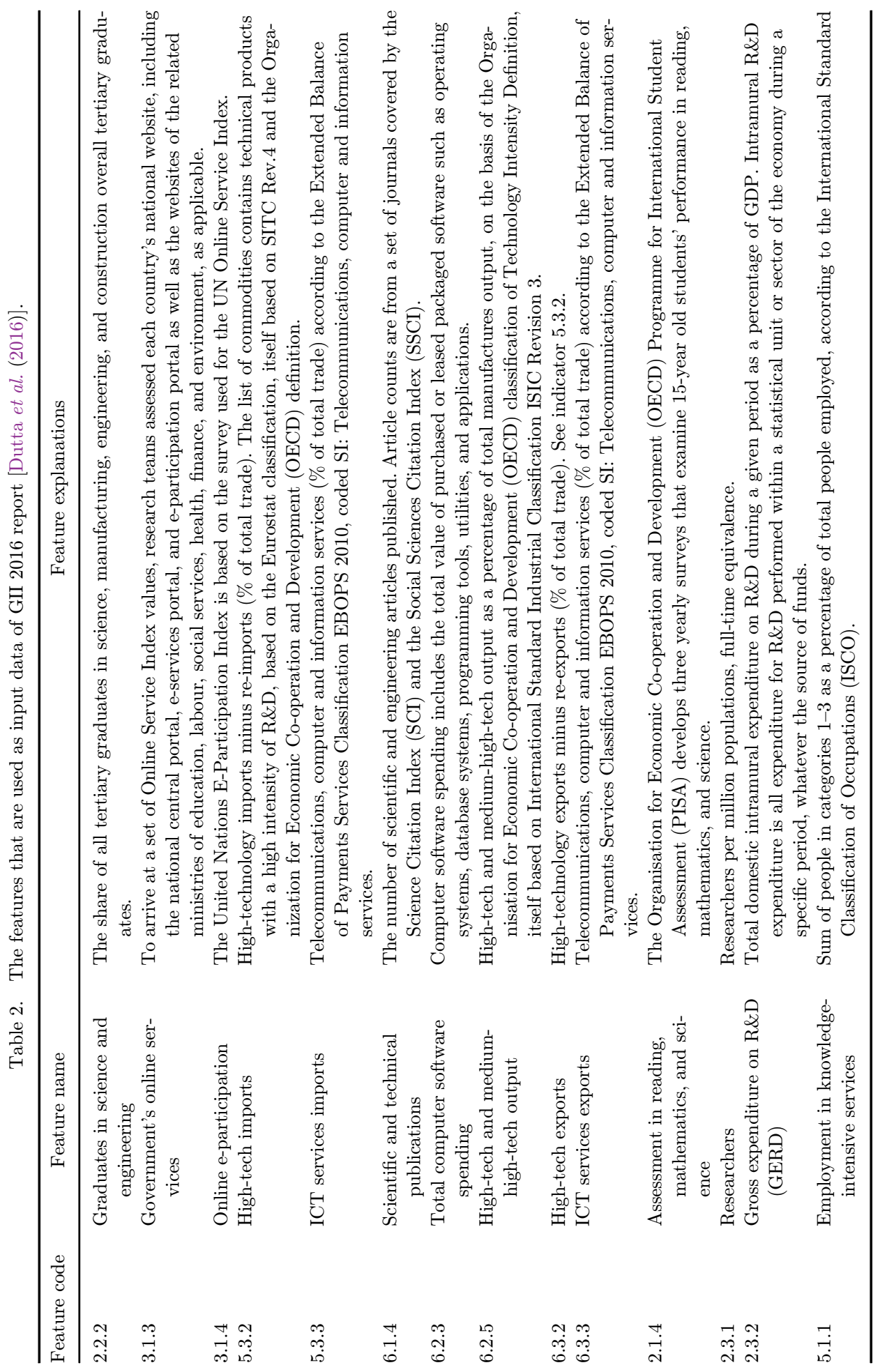




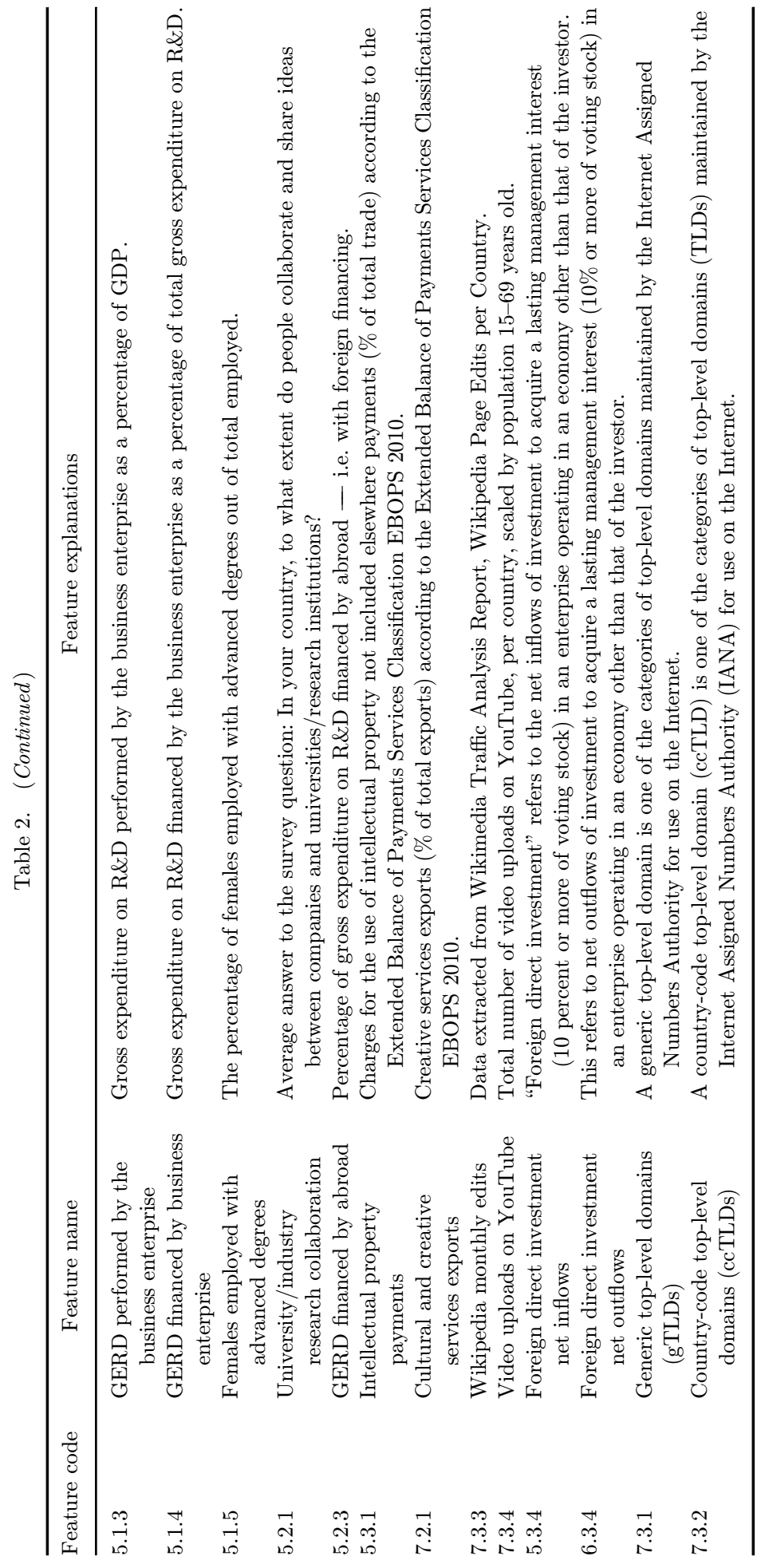




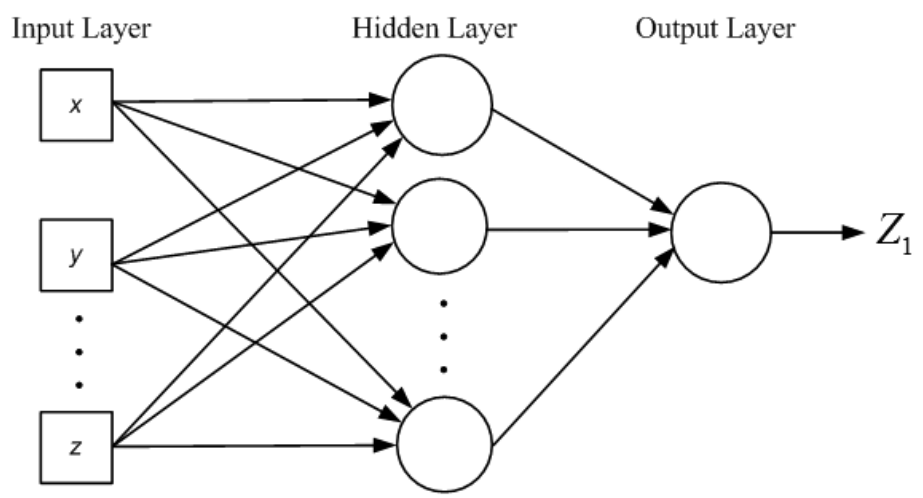

Fig. 1. ANN structure for curve fitting.

do when it is asked to make new predictions for data it has not already seen. To overcome this overfitting problem is to not use the entire data set when training a learner. The idea of this method is that once we have found our best combination of parameters on learner, we test the performance of that set of parameters in a different context. In $k$-fold cross-validation, you make a $k$ number of folds of the data, run the analysis on each fold that one of the $k$ subsets is used as the test set and the other $k-1$ subsets are put together to form a training set, and then average the overall error estimate [Ambroise and McLachlan (2002)].

Root mean square error (RMSE) is used for error calculation in the estimating process. RMSE value can calculate as in Eq. (1).

$$
\mathrm{RMSE}=\sqrt{\frac{1}{n} \sum_{i=1}^{n}\left(Z-Z_{i}\right)^{2}} .
$$

In Eq. (1), $Z$ indicates the actual score and $Z_{i}$ indicates the estimated score.

\section{Experimental Studies}

In this study, ANN is used for estimating the GII 2016 ranking scores of countries. The relevant 27 features on GII 2016 Report are chosen as an input data. The curve fitting technique is used with one output neuron in ANN design. While comparing, the estimation process is run 10 times, and the mean of values, minimum values (min), maximum values ( $\max$ ) and standard deviations (std.) of ANN estimation are given in Table 3, where "mean" indicates the average values that are obtained from the 10 running. All of the input features are normalized between 0 and 1 value. The 5 -fold cross-validation is used for estimating the test set. Various sizes of iteration and neurons are used in an experimental study.

In Table 3, the results show that different value of iteration number and neuron size affect the RMSE value of test set. The best-estimated result which has the minimum RMSE value can be seen in Fig. 2. 
Table 3. RMSE values of estimating scores for the GII 2016 data.

\begin{tabular}{lccccccc}
\hline $\begin{array}{l}\text { Iter. } \\
\text { num. }\end{array}$ & $\begin{array}{c}\text { Neuron size } \\
\text { (input-hidden) }\end{array}$ & $\begin{array}{c}\text { ANN } \\
\text { method }\end{array}$ & $\begin{array}{c}\text { Mean } \\
\text { (train) }\end{array}$ & $\begin{array}{c}\text { Mean } \\
\text { (test) }\end{array}$ & $\begin{array}{c}\text { Min } \\
\text { (test) }\end{array}$ & $\begin{array}{c}\text { Max } \\
\text { (test) }\end{array}$ & $\begin{array}{c}\text { Std. } \\
\text { (test) }\end{array}$ \\
\hline \multirow{2}{*}{100} & $50-20$ neuron & SCG & 1.084 & 3.409 & 3.228 & 3.910 & 0.202 \\
& & BR & 0.941 & 3.642 & 3.388 & 3.829 & 0.135 \\
100 & $50-10$ neuron & SCG & 1.604 & 3.534 & 3.338 & 3.722 & 0.136 \\
& & BR & 0.945 & 3.820 & 3.544 & 4.009 & 0.147 \\
100 & \multirow{2}{*}{$20-20$ neuron } & SCG & 0.986 & 3.707 & 3.339 & 4.103 & 0.236 \\
& & BR & 0.460 & 4.173 & 3.758 & 4.456 & 0.238 \\
100 & $20-10$ neuron & SCG & 1.244 & 3.705 & 3.357 & 3.999 & 0.203 \\
& & BR & 0.403 & 4.556 & 4.233 & 4.789 & 0.188 \\
10 & $50-20$ neuron & SCG & 6.288 & 6.425 & 4.933 & 8.024 & 1.153 \\
& & BR & 3.232 & 3.777 & 3.331 & 4.386 & 0.329 \\
10 & $50-10$ neuron & SCG & 8.922 & 8.990 & 7.654 & 10.315 & 0.772 \\
& & BR & 4.216 & 4.619 & 3.832 & 5.955 & 0.591 \\
10 & \multirow{2}{*}{$20-20$ neuron } & SCG & 5.025 & 5.323 & 4.384 & 6.476 & 0.709 \\
& & BR & 2.395 & 3.216 & 3.156 & 3.254 & 0.030 \\
10 & \multirow{2}{*}{$20-10$ neuron } & SCG & 6.791 & 7.219 & 5.830 & 8.493 & 0.755 \\
& & BR & 2.763 & 3.447 & 3.175 & 3.915 & 0.201 \\
\hline
\end{tabular}

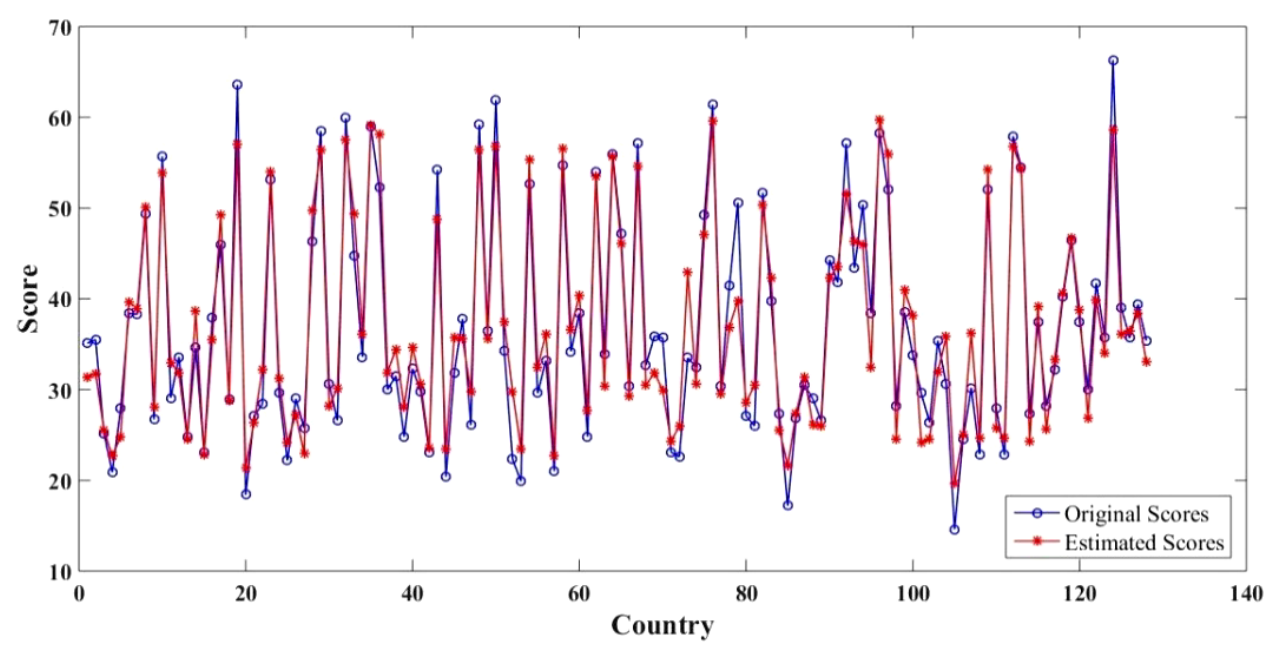

Fig. 2. Results of the ANN fitting of GII 2016 scores.

Original scores and estimated scores using ANN fitting can be seen in Fig. 2. Countries are randomly sorted and cross-validated for testing. The RMSE value is 3.216 in Fig. 2 for the parameters of ANN which iteration number is 10, input neuron size is 20 , hidden neuron size is 20 , and output neuron size is 1 . Also, BR algorithm as a method of ANN performs the best RMSE value. The parameters of ANN that results in the best RMSE value can also be seen in Fig. 3.

In Fig. 2, it can be seen that estimating scores can follow the original scores. The low RMSE value and standard deviations in Table 2 show that chosen parameters of ANN are good enough for estimating the ranking scores of countries. The results 


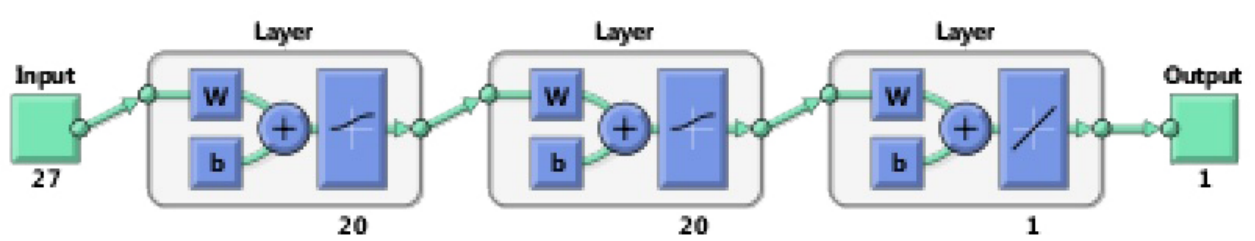

Fig. 3. ANN structure for best mean value.

indicate that the model can predict the GII score of a country using only 27 out of 82 features. Consequently, if a country wants to improve its ranking on the GII list, it needs to improve only these selected features. According to the results obtained, scores belonging to countries can only be represented with attributes in the field of innovation and technology. Therefore, these features should be the areas where the countries should be given top priority in the Industry 4.0 period.

\section{Conclusion and Discussions}

Today, Industrial 4.0 is rising all over the world and enterprises are trying to acquire places in markets for themselves with technological products based on the information. So, in today's competitive environment, the driving forces of organizations and countries are technology and innovation. More efforts and high R\&D expenditure are needed to innovation growth levels in low-and middle-income economies. Communities should spread innovation more systematically to drive global technology growth in low-and middle -income economies. Moreover, emerging countries must spend a great share of their research budget and they focus on innovation. Science and innovation are more internationalized and collaborative than ever before. All stand to gain from global innovation. For example, more innovation investments are conducted today than at any other time, with international openness the potential for global knowledge spillovers are on the rise and innovation actors in emerging countries now make meaningful contributions to local and global innovation. New ideas are emerging in different parts of the globe and successful innovation strategies have to leverage them effectively. Identifying barriers to global cooperation and the flow of ideas should be a new innovation policy priority. Financial incentives, grants, and other national innovation policies should support international collaboration and the diffusion of knowledge across borders more explicitly.

In all scenarios with innovative dynamics and growth perspectives, innovation activities exceed the boundaries of the sectors. Today, the blurring of borders has become an important part of the policies for Industry 4.0, Cyber-Physical Systems and Internet of Things. The "Green Cars — You Can Have It All" scenario in the automotive industry is not merely integrating technologies from different sectors such as multimedia to create lifestyles but is also based on narrowing the boundaries. When electric cars become part of the electric network, it is predicted that transportation and energy will combine. A recent example underlining the significance of the blurring boundaries is reflected in the notion of Industry 4.0 or Digital/Smart Manufacturing [Weber and Schaper-Rinkel (2017)]. 
The GII is produced jointly by WIPO and two business schools - INSEAD and the SC Johnson College of Business at Cornell University and seeks to shed light on countries' competitiveness based on 82 indicators. In this study, we tried to use artificial techniques in the field of computer science for analyzing the innovation data and establishing a model. Building a good model to data gives some information about original dataset. Estimating future values or getting characteristic information about data can be possible using the model. So, we proposed the estimating of ranking scores of 128 countries using ANN. We chose the relevant 27 features on GII 2016 Report, as input data and fit it with one neuron on the output layer of ANN. The low RMSE value which is obtained using ANN shows that the fitting structure is good enough to determine the approximate score of countries in the GII list. The fitting structure also shows that the estimated values can follow the original data and this ANN structure can assist Nations to improve their innovative technologies and their economies.

Building a new computational model which has fewer parameters against the standard model using on GII Report also provides the Countries with an opportunity to observe their growing progress more easily. The countries can direct their attention to these selected fields using the established model. In this study, the parameters of the countries in terms of innovation were evaluated and the positions of the countries were compared in terms of ranking. The statistical method for calculating the country's score with the ANN model generated can be modelled approximately. In this way, without using all the parameters and knowing the country's score calculation method, the score of the countries can be calculated through the established model. By examining and comparing the values obtained, countries will be able to determine their own strategies and decide which areas they will focus on. Unlike the other statistical methods, ANN is a predictive model, which allows to change the input parameters and to have knowledge about the changes in the countries' positions. Thus, countries will not need to improve all of their parameters, at least at the beginning they can track and try to improve those parameters that will provide the maximum benefit.

In view of the fact that, the only data used in this study is the GII data, this research has a limitation. So, an application to other indices that evaluate other elements of innovation systems may be not good enough with these parameters of ANN. Another limitation of this study is that countries' class not belongs to only their scores. So, developed ANN model can't estimate the countries' classes.

In future studies, we will optimize the best feature values that make Turkey enter the HI class. The Artificial intelligence method that will be used in the future studies will try to find the minimum effort around the 27 features on GII 2016 Report, for growing. Furthermore, a new classification process that group countries by their scores can be studied in the future too.

\section{Acknowledgment}

An earlier version of this paper was presented at the 13th International Strategic Management Conference on 6-8 July 2017, in Podgorica, Montenegro. 


\section{References}

Adem, A. M. and Vuran, B. (2018). Why does turkey have a chronic current account deficit? An emprical analysis. International Journal of Academic Research in Accounting, Finance and Management Sciences, 8, 1: 104-118.

Ambroise, C. and McLachlan, G. J. (2002). Selection bias in gene extraction on the basis of microarray gene-expression data. Proceedings National Academy of Sciences USA, 99, 10: $6562-6566$.

Baranenko, S. P., Dudin, M. N., Ljasnikov, N. V. and Busygin, K. D. (2014). Use of environmental approach to innovation-oriented development of industrial enterprises. American Journal of Applied Sciences, 11, 2: 189-194.

Bouchet, M. H., Clark, E. and Groslambert, B. (2003). Country Risk Assessment: A Guide to Global Investment Strategy. John Wiley \& Sons, Inc, Hoboken, New Jersey.

Brown, C. L., Cavusgil, S. T. and Lord, A. W. (2015). Country-risk measurement and analysis: A new conceptualization and managerial tool. International Business Review, 24, 2: $246-265$.

Cetişli, B. (2006). Öznitelik Seçiminde Dilsel Kuvvetli Sinir Bulanık Sınıflayıcı Kullanımı. Eskişehir Osmangazi Üniversitesi Mühendislik ve Mimarlı Fakültesi Dergisi, 19, 2: 109-130.

Coccia, M. (2007). A new taxonomy of country performance and risk based on economic and technological indicators. Journal of Applied Economics, 10, 1: 29-42.

Crespo, N. F. and Crespo, C. F. (2016). Global innovation index: Moving beyond the absolute value of ranking with a fuzzy-set analysis. Journal of Business Research, 69: $5265-5271$.

Cruces, J. A., Buscaglia, M. and Alonso, J. (2002). The term structure of country risk and valuation in emerging markets. http://papers.ssrn.com/sol3/papers.cfm?abstract_id= 327301.

Cukier, K. and Mayer-Schoenberger, V. (2013). The rise of big data: How it's changing the way we think about the world. Foreign Affairs, 92, 3: 28-40.

Dutta, S., Lanvin, B. and Wunch-Vincent, S. (2016). The Global Innovation Index 2016: Winning with Global Innovation. Cornell University, INSEAD and WIPO, Geneva.

Ersoz, F. (2009). Avrupa inovasyon göstergeleri (EIS) 1şığında Türkiye'nin konumu. Journal of Istanbul Technical University B, 6, 1: 3-16.

Funston, F. and Wagner, S. (2010). Surviving and Thriving In Uncertainty: Creating The Risk Intelligent Enterprise. John Wiley \& Sons, Inc, Hoboken, New Jersey.

Hancioglu, Y. (2016). Kuresel inovasyon endeksini olusturan inovasyon girdi ve cikti gostergeleri arasındaki iliskinin kanonik korelasyon analizi ile incelenmesi: OECD ornegi. Abant Izzet Baysal University. Journal of Social Sciences Institute, 16, 4: 131-157.

Kantos, T. (2016). On the perceptions of innovation or Ar-Ge of marketing companies operating in the automotive industry in the global competitive environment: Mersin example. Master's Thesis, Toros University.

Karadeniz, Y. Y., Yilmaz, M., Yigitbasi, M. E. and Coban, O. (2016). Analysis of competitiveness of provinces in Turkey with the help of innovation index: Level-III. SocioEconomy, 24, 30: 71-90.

Kogan, A. and Lejeune, M. A. (2015). Combinatorial Methods for Constructing Credit Risk Ratings. Handbook of Financial Econometrics and Statistics, Springer, New York, NY.

Lee, A., Mudambi, R. and Cano-Kollmann, M. (2016). An Analysis of Japan's Connectivity to the Global Innovation System. Multinational Business Review, 24, 4: 399-423.

Lee, C. C., Lee, C. C. and Ning, S. L. (2017). Dynamic relationship of oil price shocks and country risks. Energy Economics, 66: 571-581.

Lee, C. C. and Lee, C. C. (2018). The impact of country risk on income inequality: A multilevel analysis. Social Indicators Research, 136, 1: 139-162. 
Liu, C., Sun, X., Chen, J. and Li, J. (2016). Statistical properties of country risk ratings under oil price volatility: Evidence from selected oil-exporting countries. Energy Policy, 92: 234-245.

Nath, H. K. (2008). Country Risk Analysis: A Survey of the Quantitative Methods. Working Paper Series. Sam Houstan State University, 1-31.

Oetzel, J. M., Bettis, R. A. and Zenner, M. (2001). Country risk measures: How risky are they? Journal of World Business, 36, 2: 128-145.

Ozturk, Y. and Usakli, A. (2013). Global Inovasyon Endeksi: Akdeniz Canagindaki Destinasyonlara Yonelik Karsilaştirmali Bir Analiz. In 14th National Tourism Congress, Erciyes University, Kayseri, pp. 1-19.

Rahman, Z. and Bristy, J. F. (2016). Country risk analysis of Bangladesh. Journal of Commerce 85 Accounting Research, 5, 2: 7-22.

Roberts R. (1998). Managing Innovation: The Pursuit of Competitive Advantage and The Design of Innovation Intense Environments. Research Policy: 27.

Schumpeter, J. A. (1939). Business Cycles. McGraw-Hill, New York.

Schumpeter, J. A. (1962). The Theory of Economic Development. Harvard University Press, Cambridge, MA.

Simsit, Z. T., Firat, S. Ü. O., Es, H. A., Erdem, M., Topgul, M. and Gunay, N. S. (2014). Analysis of The Global Innovation Index in the Context of Information and Communication Technologies and Clustering Countries Using Data Mining. In 1st National Management Information Systems Congress, Bogaziçi University, October: 16-17, 2014, pp. 42-42.

Sohn, S. Y., Kim, D. H. and Jeon, S. Y. (2016). Re-evaluation of global innovation index based on a structural equation model. Technology Analysis 83 Strategic Management, 28, 4: $492-505$.

Tezcan, N. (2015). Comparative analysis of EU C-countries and Turkey in terms of innovation performance. Research Journal of Business $\&$ Management, 2, 2: 204-219.

Usman, K. and Liu, Z. (2015). Innovation index framework to measure the innovation capacity and efficiency of SAARC countries. European Journal of Social Sciences, 46, 3: $325-338$.

Unlukaplan, I. (2009). Avrupa Birligi uyesi ulkelerde iktisadi kalkinma, rekabetcilik ve inovasyon iliskilerinin kanonik korelasyon analizi ile belirlenmesi. Maliye Dergisi, 157: $235-250$.

Vernimmen, P., Quiry, P., Dallocchio, M., Le Fur, Y. and Salvi, A. (2014). Corporate Finance: Theory and Practice, 4th ed. John Wiley \& Sons, Inc, Hoboken, New Jersey.

Weber, K. M. and Schaper-Rinkel, P. (2017). European sectoral innovation foresight: Identifying emerging cross-sectoral patterns and policy issues. Technological Forecasting and Social Change, 115: 240-250.

Wunsch-Vincent, S., Lanvin, B. and Dutta, S. (2015). The Global Innovation Index 2015: Effective Innovation Policies for Development. Cornell University, INSEAD and WIPO.

Yang, Y., Li, J., Sun, X. and Chen, J. (2014). Measuring external oil supply risk: A modified diversification index with country risk and potential oil exports. Energy, 68: 930-938.

\section{Biography}

İhsan Pençe is an Assistant Professor of Management Information Systems at Burdur Mehmet Akif Ersoy University, Turkey. He holds a PhD from Computer Engineering at Süleyman Demirel University.

Adnan Kalkan is an Associate Professor of Business Management and Strategy at Burdur Mehmet Akif Ersoy University, Turkey. He holds a PhD from Business Administration at Gebze Institute of Technology. He previously served as head of Management Information Systems Department and now serving as manager of 
Business School at this University. His research focuses on business management and information systems.

Melike Şişeci Çeşmeli is an Assistant Professor of Management Information Systems at Burdur Mehmet Akif Ersoy University, Turkey. She holds a PhD from Computer Engineering at Süleyman Demirel University. 